УДК 346.31

DOI https:/ / doi.org/10.32837/yuv.v0i2.1706

\author{
В. Попелюк, \\ кандидат юридичних наук, \\ доцент кафедри господарського права і процесу \\ Національного університету «Одеська юридична академія»

\section{Ю. Мустафаєв,} \\ юрисконсульт \\ Товариства з обмеженою відповідальністю \\ з іноземними інвестиціями «Трансінвестсервіс»

\section{ДО ПИТАННЯ НЕДІЙСНОСТІ ГОСПОДАРСЬКОГО ДОГОВОРУ 3 ПІДСТАВ УЧИНЕННЯ ГОСПОДАРСЬКИХ ОПЕРАЦІЙ 3 ОЗНАКАМИ ФІКТИВНОСТІ (НЕРЕАЛЬНОСТІ)}

Небезпека вчинення господарських операцій з ознаками фіктивності (нереальності) чи, іншими словами, нереальних господарських операцій може стати підставою для визнання договору 3 боку контролюючих органів недійсним, і наслідком для суб'єкта господарювання стає те, що всі витрати (або податковий кредит) за таким договором, які використано в розрахунку об'єктів оподаткування (податку на прибуток, податку на додану вартість (далі - ПДВ)), втрачають свою юридичну силу через застосування відповідної податкової відповідальності.

За даними Державної казначейської служби України, за період січня-березня 2020 р., тобто ще до початку світової кризи, викликаною пандемією коронавірусної хвороби COVID-19, невиконання плану державного бюджету України податковими та митними органами (тут і далі - контролюючі органи, органи доходів і зборів) становило понад 26,39 мільярдів гривень (6,5 мільярдів гривень від податкових органів та 19,85 мільярдів - від митних органів), що в процентному співвідношенні становить $13 \%$ від запланованих надходжень до держбюджету України [1].

Слід зазначити, що однією з причин невиконання держбюджету є так звані «скрутки» з ПДВ, які, за заявою коли- шнього міністра фінансів Ігоря Уманського, призводять до неотримання держбюджетом у середньому близько 5 мільярдів гривень на місяць [2]. Так звані «скрутки» $з$ ПДВ являють собою вчинення суб'єктами господарювання нереальних господарських операцій, що призводить до незаконного формування податкового кредиту з ПДВ [3, с. 15]. Більше того, проблема нереальних господарських операцій стосується не тільки ухилення від сплати ПДВ, а й інших податків, зокрема податку на прибуток підприємств та податку на доходи фізичних осіб, унаслідок чого це призводить до розвитку тіньового сектору економіки і ненадходження податків до бюджету.

Однак у законодавстві України взагалі відсутнє поняття нереальних (фіктивних) господарських операцій, так само як і єдині критерії та методи визнання господарських операцій нереальними, але $з$ огляду на існуючу судову практику, рекомендації контролюючих органів та практику ділового обороту наводяться ознаки фіктивності (нереальності) таких операцій. Для прикладу, це може бути наявність або відсутність господарської мети договору, наявність або відсутність спеціальної правосуб'єктності та ін.

Це, своєю чергою, призводить до неоднакового застосування норм права 
як контролюючими органами під час проведення перевірок платників податків, так і судами під час розгляду справ щодо оскарження податкових повідомлень-рішень, щодо операцій з ознаками фіктивності (нереальності).

Питання щодо господарських операцій 3 ознаками фіктивності (нереальності), які можуть стати підставою для визнання договору недійсним, $€$ предметом дослідження багатьох науковців, зокрема можна виділити роботи таких учених, як А.А. Аносєнков, Д.О. Гетьманцев, Ф.В. Дудчак, Р.Р. Дудчак, М.О. Матухно, Р.В. Мукоіда, М.К. Золотарьова, А.В. Лісовий, M.В. Савчин. Також слід відзначити, що питання господарських операцій з ознаками фіктивності (нереальності) неодноразово розглядалося в судах різного рівня, що сформувало певну судову практику, яка використовується контролюючими органами під час доведення факту вчинення нереальних (фіктивних господарських операцій).

Мета статті - дослідити економіко-правове явище операцій з ознаками фіктивності (нереальності), які можуть стати підставою для визнання договору недійсним.

Поняття господарської операції закріплено в ст. 1 Закону України «Про бухгалтерський облік та фінансову звітність» [4] - це дія або подія, яка викликає зміни в структурі активів та зобов'язань, власному капіталі підприємства, а поняття «нереальні» або «фіктивні» господарські операції сформовано виключно практикою контролюючих та судових органів, що, безумовно, суперечить ст. $19 \mathrm{KoH}-$ ституції України [5].

У судовій практиці поняття реальних/нереальних господарських операцій було вжито Вищим адміністративним судом України (ВАСУ) у листі № 742/11/13-11 від 02.06.2011 [6]. Правонаступник ВАСУ - Касаційний адміністративний суд у складі Верховного Суду продовжує формувати судову практику з урахуванням цього поняття: «Отже, господарські операціï, які зумовлюють наслідки у вигляді виникнення у покупця права на формування податкових вигід, мають бути фактично здійсненими та підтвердженими належним чином оформленими первинними бухгалтерськими документами, які зазвичай супроводжують операції певного виду та відображають реальність таких операцій, та спричиняти реальні зміни майнового стану платника податків. Недоведеність наявності вказаних умов позбавляе первинні документи юридичної значимості для цілей формування податкових вигід, а покупця - права на їх формування та відображення у бухгалтерському та податковому обліку» [7].

Слід зазначити, що немає єдиного підходу до визначення поняття «нереальна господарська операція» і серед науковців. Так, на думку Р.Р. Дутчак та В.Ф. Дутчак, нереальна господарська операція - це така господарська операція 3 активами сторін договору, яка документально правильно оформлена, але фактично не може бути виконана через відсутність потрібних економічних чи правових можливостей підприємства або контрагента [8, с. 94].

Важко погодитися із цим визначенням, адже зазвичай суб'єкти господарювання мають можливість виконати ту чи іншу господарську операцію, однак мета вчинення такої операції за цим визначенням - це фактично ухилення від сплати податків та обов'язкових платежів, тому наявність матеріальних або людських ресурсів у контрагентів не $€$ беззаперечним доказом реальності чи нереальності вчинення господарської операції.

Іншої думки дотримується Д.О. Гетьманцев: «Безтоварна (або нереальна. Прим. авт.) операція, тобто умисне створення платником податку ланцюга взаємопов'язаних документів, які містять у собі відомості, що не відповідають дійсності, про поставку товарів, робіт, послуг із метою отримання неправомірної податкової вигоди» [9, с. 109].

Дане визначення досить повно розкриває суть нереальних господарських операцій, оскільки оперує поняттям 
«неправомірна податкова вигода», що $€$ ключовим у складі правопорушень, пов'язаних 3 ухиленням від сплати податків.

Окремо варто відзначити, що ВАСУ сформував судову практику, згідно 3 якою поняття «нереальні/фіктивні господарські операції» не пов'язане 3 нормами цивільного та господарського законодавства щодо визнання правочинів недійсними, зокрема у Рішенні від 20.01.2015 по справі № 2a-13655/12/2670 ВАСУ зазначив: «Судами попередніх інстанцій був залишений поза увагою той факт, що господарські операції, здійснені на виконання правочинів, є самостійним поняттям, відмінним від правочинів або господарських зобов'язань, а дотримання норм цивільного чи господарського права не означає автоматично реальності вчинення господарської операції» [10].

Такий підхід підтримується і деякими науковцями. Так, Д.О. Гетьманцев уважає, що «неправильно кваліфікувати операції платника виходячи з їх правової форми, а не економічного змісту, адже податкове право здійснює правове регулювання відносин для цілей оподаткування виходячи передусім з їх економічного змісту» [9, с. 107].

Що стосується контролюючих органів, то їхня позиція грунтується, зокрема, на Методичних рекомендаціях із фіксування в актах перевірок результатів відпрацювання документально оформлених платниками податків нереальних господарських операцій (далі - Методичні рекомендаціі), викладених у Листі ДФС № 16872/7/99-99-14-02-02-17 від 16.05.2016 [11].

Контролюючі органи застосовують такі терміни для виявлення та визнання господарських операцій нереальними: «нереальне постачання (продаж)» документально оформлене постачання (продаж) відповідної кількості ідентифікованого товару за безтоварною операцією або походження якого не підтверджується фактом (джерелом) його законного введення в обіг та/або реального задекларованого виробництва (характеризується недійсністю формування відповідного активу); «нереальне одержання (купівля)» - документально оформлене одержання (купівля) ідентифікованого товару за відповідним нереальним його постачанням (продажем); «нереальна господарська операція» - операція 3 нереального постачання (продажу) та/або нереального одержання (купівлі) [11, п. 1.2].

В іншому Листі № $35277 / 7 / 99$ 99-14-02-02-17 від 02.11.2016 контролюючий орган виділив основні види нереальних господарських операцій, a саме: «товарні», що характеризуються фактичним набуттям вигодонабувачем відповідного активу (послуги), дійсне джерело походження якого невідоме; «безтоварні», коли створюється видимість придбання вигодонабувачем неіснуючих запасів (актив у дійсності не формується) чи реально не наданих послуг із безпідставним віднесенням іхньої вартості на витрати; «попередня оплата» - перерахування коштів як нібито аванс за товари/послуги з формуванням дебіторської заборгованості за операцією, яка має очевидний нереальний характер (відсутні будьякі об'єктивні обставини можливості реального постачання товарів/послуг у майбутньому) [12, п. 3.2].

Зауважимо, що Методичні рекомендації передбачають з'ясування контролюючими органами комплексу фактів, які можуть свідчити про відсутність реального характеру вчинення господарської операції, зокрема:

1. Неможливість здійснення господарської операції 3 ідентифікованим товаром у зв'язку з відсутністю факту (джерела) його законного введення в обіг та/або реального задекларованого виробництва.

2. Нездійснення та/або неможливість здійснення «продавцями» (товарів і послуг. - Прим. авт.) господарської діяльності та відповідної нереальної господарської операції.

3. Негативна інформація щодо документального оформлення нереальної господарської операції. 
4. Відсутність документа щодо підтвердження відповідності продукціі (декларації про відповідність, паспорта якості, сертифіката відповідності тощо) або відсутність у «продавців» документів дозвільного характеру, без наявності яких суб'єкт господарювання не може проваджувати певні дії щодо здійснення господарської діяльності [11, п. п. 3.1-3.1.7].

На відміну від контролюючих органів суди сформували власні підходи до визнання та доведення в господарських операціях ознак фіктивності, так звані судові доктрини - це типові підходи та методи вирішення певних судових спорів, які були розроблені в ході накопичення та подальшого узагальнення судової практики $[13$, с. 26].

Однією $з$ найпоширеніших судових доктрин, яка використовується судами під час розгляду даної категорії справ, $€$ доктрина «ділової мети», яка полягає у тому, що передбачені податковим законодавством податкові вигоди поширюються лише на операції, які мають розумну економічну причину [10].

При цьому поняття розумної економічної причини (ділова мета) закріплене в п. 14.1.232 ст. 14 Податкового кодексу України - це причина, яка може бути наявна лише за умови, що платник податків має намір одержати економічний ефект у результаті господарської діяльності [14].

Водночас Верховний Суд у Постанові від 23.07.2019 у справі № 802/2386/14-а зазначає, що мета отримання доходу як кваліфікуюча ознака господарської діяльності кореспондує з вимогою щодо наявності розумної економічної причини (ділової мети) під час здійснення господарської діяльності. Оскільки господарська діяльність складається із сукупності господарських операцій платника податку, які $€$ формою здійснення господарської діяльності, то розумна економічна причина має бути наявною в кожній господарській операції. Лише в такому разі та чи інша операція може вважатися вчиненою в межах господарської діяльності платника податку та лише за таких умов платник має право на врахування в податковому обліку наслідків відповідних господарських операцій. Отже, зміст поняття розумної економічної причини (ділової мети) передбачає обов язкову спрямованість будь-якої операції платника на отримання позитивного економічного ефекту, тобто на приріст (збереження) активів платника (їх вартість), а так само створення умов для такого приросту (збереження) в майбутньому [15].

Наступною доктриною, яка застосовується судами під час визнання господарської операції нереальною, є доктрина «перевага суті над формою», яка полягає у наявності однієї кваліфікуючої обставини, і до уваги беруться економічні наслідки за результатами здійснення господарських операцій незалежно від їх відповідного оформлення.

Так, Верховний Суд у Постанові від 13.11.2018 у справі № 822/6312/15 зазначив: «Посилання податкового органу на відсутність актів виконаних робіт форми КБ 2-В і довідки форми КБ-3 є безпідставними, оскільки надані акти виконаних робіт хоча і не відповідають за формою актам, визначеним умовами договору, проте містять усі необхідні реквізити, встановлені частиною другою статті 9 Закону № 996-XIV. Оцінюючи спір у цій частині, Суд погоджується з висновком суду апеляційної інстанції та висновується на основних принципах бухгалтерського обліку та фінансової звітності, зокрема на принципі превалювання сутності над формою, за яким операції обліковуються відповідно до їх сутності, а не лише виходячи 3 юридичної форми» [16].

Ще однією доктриною, яка доволі рідко використовується судами, $€$ доктрина «угода по крокам» (step transactions), яка полягає у визначенні податкових наслідків суб'єкта господарювання за реально вчиненим ним правочином без урахування проміжних угод, що укладаються ним із метою мінімізації податкових зобов'язань. Разом із тим, укладаючи проміжні угоди, платник податків прагне настання тих самих 
наслідків, яких би він досягнув, укладаючи одну угоду. Яскравим прикладом $є$ закупівля товару через низку посередників за наявності прямих контрактів із виробником товару, здебільшого з метою штучного завищення валових витрат. При цьому значне підвищення ціни спостерігається на контрагенті, який є так званою «податковою ямою» та взагалі не буде сплачувати податки $[17$, с. 5].

Так, Постановою Верховного Суду України від 1 вересня 2009 р. у справі № 21-1258во09 вказано, що суди не дослідили доводи податкового органу про безтоварність операцій та їх фіктивність у визначеному законодавством порядку та не взяли до уваги те, що позивач придбавав через посередника (ТОВ «Стиг») сировину, зокрема металопрокат, у осіб, діяльність яких мала ознаки фіктивного підприємництва, які за юридичною адресою не знаходилися, проти засновників яких порушено кримінальні справи, а також те, що позивач, продавець та його постачальники працювали в одному сегменті ринку, для роботи в якому необхідною умовою є ліцензія, наявність якої у перелічених осіб не було встановлено [18].

Правова проблема щодо операцій 3 ознаками фіктивності (нереальності), які можуть стати підставою для визнання договору недійсним, пов'язана 3 недоліками законодавчого регулювання суспільних відносин, які контролюючі органи намагаються виправити за допомогою ненормативних правових актів у формі листів та рекомендацій, а суди застосовують власні позиції і доктрини як джерело права під час розгляду судових спорів.

Загалом практика судових i контролюючих органів щодо віднесення поняття «нереальних (фіктивних) господарських операцій» виключно у площину податкового законодавства, нехтуючи при цьому положеннями норм цивільного і господарського законодавства, € загрозливою, оскільки надає контролюючому органу, по суті, необмежені повноваження щодо визнання будь-якої господарської операції такою, що не відбулася насправді, навіть не з'ясовуючи самої суті і мети такої операції. Зокрема, це призводить до того, що викладені в акті перевірки дотримання податкового законодавства висновки контролюючі органи формують на підставі припущень, пояснень фізичних осіб, актів інших перевірок інших платників податків.

Тому в кожному такому випадку суд постає перед проблемою, наскільки належним та допустимим доказом правомірності оскаржуваного рішення податкового органу $є$ такий акт перевірки [19]. У будь-якому разі, визнання господарської операції нереальною без відповідного визнання господарського договору недійсним суперечить принципу правової визначеності зазначеного в Рішенні Конституційного Суду України від 29.06.2010 [20].

Таким чином, виникає ситуація, коли платник податків притягується до податкової відповідальності за вчинення дій, відповідальність за які не визначена жодним нормативно-правовим актом чинного законодавства Украіни. Викладення критеріїв оцінки реальності господарських операцій у листах i рекомендаціях податкового органу також позбавляє платника податків скасувати в судовому порядку ці акти, оскільки вони не є нормативними і не створюють для такого платника жодних прав та обов'язків.

Водночас доцільним було б розподілити всіх платників податків за ступенем ризику на підставі критеріїв, які визначено в Порядку формування плану-графіка проведення документальних планових перевірок платників податків [21]. Так, контролюючий орган на підставі камеральних перевірок наявної у нього інформації буде визначати та присвоювати кожному платнику податків ступень ризику від незначного до високого за критеріями та оприлюднювати таку інформацію.

Такий підхід дасть змогу суб'єктам господарювання уникати співпраці 3 ризиковими контрагентами, а якщо все ж таки платник податків здійснив 
господарську операцію 3 ризиковим платником податків, буде легше довести його вину в учиненні нереальної господарської операції, оскільки він знав або мав можливість перевірити обставини, за якими його контрагент віднесений до високого ступеню ризику. Своєю чергою, у разі незгоди платники податків зможуть оскаржувати рішення контролюючих органів про призначення їм відповідного ступеня ризику у судовому або адміністративному порядку.

Зазначений механізм суттєво зменшить кількість оскаржень податкових повідомлень-рішень та полегшить формування доказової бази контролюючими органами під час визнання господарських операцій нереальними.

Цікавим є те, що Законом України № 466-IX від 16.01.2020 внесено зміни до Податкового кодексу України та введено поняття економічного ефекту, який є обов'язковою умовою наявності розумної економічної причини (ділової мети) господарської операції.

Економічний ефект передбачає приріст (збереження) активів платника податків та/або їх вартості, а так само створення умов для такого приросту (збереження) в майбутньому. При цьому для цілей оподаткування вважається, що операція, здійснена з нерезидентами, не має розумної економічної причини (ділової мети), зокрема, але не виключно, якщо:

- головною ціллю або однією з головних цілей операції та/або їі результатом є несплата (неповна сплата) суми податків та/або зменшення обсягу оподатковуваного прибутку платника податків;

- у зіставних умовах особа не була б готова придбати (продати) такі роботи (послуги), нематеріальні активи, інші предмети господарських операцій, відмінні від товарів, у непов'язаних осіб [22].

Тому задля вирішення питання господарських операцій 3 ознаками фіктивності (нереальності) чи, іншими словами, нереальних господарських операцій доцільним було б уведення вище- зазначених критеріїв відсутності розумної економічної причини (ділової мети) не тільки на операціі, здійснені з нерезидентами, а й на операції між резидентами, оскільки здебільшого нереальні господарські операції вчиняються саме між суб'єктами господарювання, зареєстрованими на території України.

Також слід доповнити вищевказану норму пунктом про те, що відсутність розумної економічної причини (ділової мети) господарської операції $€$ підставою для визнання такої операції нереальною та позбавлення податкових вигід платника податків, які він отримав від учинення такої операціі. Додатково включити поняття «розумна економічна мета» та «економічний ефект» в положення Господарського кодексу України щодо господарських договорів і визначити, що відсутність економічного ефекту та разом із ним і розумної економічної мети тягне за собою недійсність господарського договору. Уведення цих понять у Господарський кодекс України зобов'яже контролюючі органи визнавати господарські операції платників податків нереальними виключно в судовому порядку і попередить зловживання з боку органів доходів і зборів під час кваліфікації дій платника.

Статтю присвячено господарським операціям з ознаками фіктивності (нереальності), які можуть стати підставою для визнання договору недійсним. Оскільки укладання господарських договорів, а відповідно, i оформлення господарських операцій з ознаками фіктивності (нереальності) на підставі таких договорів - ие проблема, яка стосується суб'єктів господарювання, котрі використовують відповідні документи для формування податкових показників по витратах із податку на прибуток ma податкового кредиту з податку на додану вартість, що не виключає ü іншuх податків.

y cmammi розкрито сутність нереальної господарської операціі, наведено їі типові ознаки, зокре- 
ма розумної економічної причини (ділова мета); економічних наслідків за результатами здійснення господарських операцій незалежно від їх відповідного документального оформлення; визначених податкових наслідків суб'єкта господарювання за реально вчиненим ним правочином без урахування проміжних угод, що укладаються ним із метою мінімізаиіï податкових зобов'язань.

Проаналізовано, щзо судова практика за останні 10 років зазнае змін до більи сурового трактування законодавства не на користь суб'єктів господарювання, що проявляється в додаткових вимогах (доказах) правомірності вчинення господарських операції й які не передбачено чинним законодавством. Фактично судова практика йде иляхом з'ясування контрагента (ів) суб'єкта господарювання, а не з'ясування реальності господарської операції.

Запропоновано зміни до положень законодавства як щодо забезпечення реальності господарської операиіi, так $і$ для забезпечення дійсноcmi господарських договорів, зокрема розповсюдження положень розумної економічної причини (ділової мети) не тільки на операції, здійснені з нерезидентами, а й на операції між резидентами та доповнення в положення Господарського кодексу Украіни щзодо господарських договорів.

Ключові слова: нереальна господарська операція, господарський договір, недійсний договір.

Popeliuk V. Mustafaev Yu. On the issue of invalidity of the economic agreement on the grounds of conducting economic operations with signs of fictivity (unreality)

The article is devoted to business transactions with signs of fictitiousness (unreality), which may become the basis for recognizing the contract as fictitious. Since the conclusion of business agreements, and consequently the execution of business transactions with signs of fictitiousness (unreality) on the basis of such agreements is a problem that concerns businesses that use the relevant documents to form tax indicators on income tax expenses and tax credit. value added, which does not exclude other taxes.

The article reveals the essence of an unrealistic business transaction, gives its typical features. In particular, a reasonable economic reason (business purpose); economic consequences of the results of business transactions, regardless of their relevant documentation; certain tax consequences of the business entity for the transaction actually made by him, without taking into account the interim agreements entered into by him in order to minimize tax liabilities.

It is analyzed that the case law for the last 10 years has undergone changes to a stricter interpretation of the law not in favor of business entities, which is manifested in additional requirements (evidence) of the legality of business transactions and not provided by current legislation. In fact, the case law follows the path of finding out the counterparty $(s)$ of the entity, rather than finding out the reality of the transaction.

Amendments to the provisions of the legislation are proposed, both to ensure the reality of the business transaction and to ensure the validity of business agreements. Thus, the extension of the provisions of reasonable economic reason (business purpose) not only to transactions carried out with nonresidents, but also to transactions between residents and additions to the provisions of the Commercial Code of Ukraine on commercial contracts.

Key words: unreal business transaction, business contract, invalid contract.

\section{Література}

1. Виконання Держбюджету Украіни за доходами, надходження до місиевих бюджетів та ЄCB. Офіційний сайт Державної казначейської служби України. URL : https://www.treasury.gov.ua/ ua/news / informatsiya-pro-vikonannya- 
derzhavnogo-byudzhetu-ukraini-zadokhodami-nadkhodzhennya-do-mistsevikhbyudzhetiv-ta-esv.

2. Ігор Уманський: «Від «скруток» iз ПДВ бюджет недоотримує в середньому 5 мільярдів на місяць». LB.UA. URL:https: // ukr.lb.ua/economics / 2020/04/02 / 454302_ igor_umanskiy_vid_skrutok_iz_pdv.html.

3. Дубровський В., Черкашин В., Гетьман О. Порівняльний аналіз фіскального ефекту від застосування інструментів ухилення/уникнення оподаткування в Україні: нові виклики. URL : http:// www.visnuk.com.ua / ru/news / 100014336 porivnyalniy-analiz-fiskalnogo-efektu-vidzastosuvannya-instrumentiv-ukhilennyauniknennya-opodatkuvannya-v-ukrayini-2019.

4. Закон України «Про бухгалтерський облік та фінансову звітність в Україні» № 996-XIV від 16.07.1999. Відомості Верховної Ради України. 1999. № 40. Cm. 365.

5. Конституція України від 28.06.1996. Відомості Верховної Ради України (ВВP). 1996. № 30. Cm. 141 .

6. Лист Вищого адміністративного суду України № 742/11/13-11 від 02.06.2011. «Щодо однакового застосування адміністративними судами окремих приписів Податкового кодексу України та Кодексу адміністративного судочинства України». Податки та бухгалтерський облік. 2011. № 49. Cm. 11 .

7. Постанова Верховного Суду від 09.08.2019 у справі № 826/14878/13-a. URL : http: / / reyestr.court.gov.ua/Review/ 75805489 .

8. Дутчак Р.Р., Дутчак В.Ф. Управлінський контроль над обліково-аналітичним забезпеченням вирішення господарських спорів щодо нереальних господарських операщій підприємства. Економічна теорія та право. 2019. № 2(37). С. 89-104.

9. Гетьманцев Д.О. Податкова кваліфікація дій платників ПДВ у контексті протидї ухиленню від оподаткування ПДВ. Часопис Київського університету права. 2013 /3. C. 106-112.

10. Ухвала Вищого адміністративного суду України від 20.01.2015 у справі № 2a-13655/12/2670. URL : http:// reyestr.court.gov.ua/Review/42609165.

11. Лист Державної фіскальної служби України №16872/7/99-99-14-02-02-17 віо 16.05.2016 «Про фіксування в актах перевірок результатів відпрацюювання документально оформлених платниками податків нереальних господарських операцій». Баланс. 2018. № 68-69. С. 31 .
12. Лист Державної фіскальної служби України № 35277/7/99-99-14-02-02-17 від 02.11.2016 «Про рекомендації щодо наведення інформаиї з окремих питань в актах документальних перевірок вигодонабувачів схемного податкового кредиту». Баланс. 2017. № 74-75. C. 23.

13. Мохов Р.М. Судебная доктрина как источник права. Политика, экономика и инновации. 2018. № 4(21). URL: https:// cyberleninka.ru/article / $n$ / sudebnayadoktrina-kak-istochnik-prava.

14. Податковий кодекс України від 02.12.2010 № 2755-VI. URL : https: / / zakon.rada.gov.ua/laws/show/2755-17.

15. Постанова Верховного Суду від 23.07.2019 у справi № 802/2386/14-a. URL : http: / / reyestr.court.gov.ua / Review / 83304347.

16. Постанова Верховного Суду від 13.11.2018 y справі № 822/6312/15. URL : http: / / reyestr.court.gov.ua/Review / 77828686\#.

17. Білецька Г.М. Окремі аспекти застосування судових доктрин при розкритті податкових злочинів: світові та історичні тендениіi. Фінансове право. 2013. № 2(24). C. 4-6.

18. Постанова Верховного Суду від 22.11.2016 у справі № 21-2430a16. URL : https: / / protocol.ua/ru/vsu_dokumenti_ vidani_kontragentom_zasudgenim_za_fiktione_ pidpriemnitstvo/.

19. Узагальнення та аналіз судової практики щодо адміністрування податку на прибуток підприємств. Шостий апеляційний адміністративний суд. URL : https:// 6aas.gov.ua/ua/law-library/court-practice/ kijioskij-apelyatsijnij-administrationij-sud/ uzagalnennya-ta-analiz-sudovoji-praktikishchodo-administruvannya-podatku-napributok-pidpriemsto.html.

20. Рішення Конституційного Суду України від 29.06.2010 № 17-pn/2010. Вiсник Конституційного Суду Украӥни. 2010. № 5. C. 11 .

21. Наказ Мінфіну України № 524 від 02.06.2015 «Порядок формування плану-графіка проведення документальних планових перевірок платників податків». Офіційний вісник України. 2015. № 57. С. 141. Cm. 1873.

22. Закон України № 466-IX від 16.01.2020. «Про внесення змін до Податкового кодексу України щодо вдосконалення адміністрування податків, усунення технічних та логічних неузгодженостей у податковому законодавстві». Голос України. 2020. № 84 . 